\title{
A review of the genus Bulbothrix Hale: the species with medullary norstictic or protocetraric acids
}

\author{
Michel N. Benatti \\ I Instituto de Botânica, Núcleo de Pesquisa em Micologia, Caixa Postal 68041, São Paulo / SP, CEP 04045- \\ 972, Brazil \\ Corresponding author: Michel N. Benatti (michel_benatti@yahoo.com.br)
}

Academic editor: P. Divakar | Received 8 December 2011 | Accepted 13 February 2012 | Published 5 March 2012

Citation: Benatti MN (2012) A review of the genus Bulbothrix Hale: the species with medullary norstictic or protocetraric acids. MycoKeys 2: 1-28. doi: 10.3897/mycokeys.2.2522

\begin{abstract}
This study presents data of eight Bulbothrix (Parmeliaceae, Lichenized Fungi) species containing norstictic or protocetraric acid in the medulla. The current species delimitations were confirmed. New synonyms are proposed, new characteriscts are detailed and range extensions are added.
\end{abstract}

\section{Key words}

Parmeliaceae, salazinic acid, bulbate cilia

\section{Introduction}

Bulbothrix Hale was proposed for the group of species called Parmelia Series Bicornutae (Lynge) Hale \& Kurokawa (Hale 1974), characterized by small, laciniate and usually adnate thalli, bulbate marginal cilia, cortical atranorin, simple to branched cilia and rhizinae, smooth to coronate apothecia, hyaline unicellular ellipsoid to bicornute ascospores 5.0-21.0 × 4.0-12.0 $\mu \mathrm{m}$, and bacilliform to bifusiform conidia 5.0-10.0× 0.5-1.0 $\mu \mathrm{m}$ (Hale 1976, Elix 1993). In a recent paper presenting a revised generic concept of Parmelioid lichens based on molecular, morphological and chemical evidence (Crespo et al. 2010) include other diagnostic features such as pored epicortex, lack of pseudocyphellae, and presence of isolichenan in the cell walls. Bulbothrix is currently nested in the Parmelina clade and some species are grouped with Parmelinella, making the genus paraphyletic (Crespo et al. 2010). 
During a revision of the genus Bulbothrix (Benatti 2010) the type specimens and additional material of Bulbothrix species were studied. These species have cilia with hollow basal bulbs, which contain differentiated cells and a characteristic oily substance (Hale 1975, Feuerer and Marth 1997, Benatti 2011). This paper discusses the seven species with medullary norstictic acid [Bulbothrix cinerea Marcelli \& Kalb, B. lordhowensis Elix, B. haleana Sérusiaux, B. subcoronata (Müller Argoviensis) Hale, B. regnelliana Jungbluth, Marcelli \& Elix, B. ventricosa (Hale \& Kurokawa) Hale, and B. viatica Spielmann \& Marcelli], and the single species with protocetraric acid [Bulbothrix chowoensis (Hale) Hale]. New combinations of four species, Hypotrachyna tuskiformis (Elix) Benatti \& Marcelli, Parmelinopsis pinguiacida (Louwhoff \& Elix) Marcelli \& Benatti, $P$. subinflata (Hale) Benatti \& Marcelli and Parmotrema yunnanum (Sheng L. Wang, J.B. Chen \& Elix) Marcelli \& Benatti, previously placed in Bulbothrix (Benatti \& Marcelli 2010) were already published after their exclusion due to the lack of true bulbate cilia.

\section{Material and methods}

Type material and additional species were studied from B, BM, CANB, DUKE, G, ICN, NY, SP, TUR, UPS, US and from Dr. Klaus Kalb's personal herbarium, originating from Oceania, Asia, North Pacific, Africa, North America, Central America, Caribbean and South America, as well as material collected in Brazil during the last 30 years, mainly by the author and the members of the Lichenological Study Group of the Instituto de Botânica (GEL) in Brazil.

The morphological and anatomical characters of the specimens were analyzed using standard stereoscopic and compound microscopes. Anatomical sections, including those of apothecia and pycnidia when present, were made with a razor blade by hand. Bulbs on cilia, rhizines, apothecia and other thallus parts were checked using the clarification method (Benatti 2011) The chemical constituents were checked by spot tests with potassium hydroxide (K), sodium hypochlorite $(\mathrm{C})$ and para-phenylenediamine $(\mathrm{P})$, and also examined under UV light $(360 \mathrm{~nm})$. Chemical constituents of the additional specimens examined were identified by thin-layer chromatography (TLC) using solvent C (Bungartz 2001), and compared with the data on labels left with the specimens. The types had their chemical constituents examined by high performance liquid chromatography (HPLC), following the methods described in Elix et al. (2003).

The presence of norstictic acid is evidenced by a $\mathrm{K}+$ yellow $\rightarrow$ orange or bright red spot test reaction. Its presence is easily confirmed by the formation of tiny star shaped crystals, observed under a light microscope after the transfer of hyphae onto a microscope slide and dropping the reagent on the fungal material, such as cutting a small piece of the thallus or of the apothecia. Protocetraric acid is detected by $\mathrm{KC}+$ rose and $\mathrm{P}+$ reddish orange spot tests reactions, and do not form crystals using $\mathrm{K}$ reagent.

The species selected for comparisons are those who show close morphological or chemical similarities, and those most often compared by other authors due to peculiar characteristics. 


\section{Results and discussion}

The study confirmed seven species containing medullary norstictic acid and one species containing medullary protocetraric acid. Of these, Bulbothrix cinerea, B. lordhowensis and $B$. ventricosa are isidiate, while $B$. chowoensis, $B$. haleana, $B$. subcoronata, $B$. regnelliand and $B$. viatica only form apothecia. All species are corticicolous with the exception of $B$. haleana and $B$. cinerea, which are saxicolous. The only confirmed species containing medullary protocetraric acid is $B$. chowoensis.

\section{The species}

\section{Bulbothrix chowoensis (Hale) Hale. Phytologia 28(5): 480.1974.} Mycobank: MB 341593

Figures 1-2

Basionym. Parmelia chowoensis Hale. Phytologia 23: 343. 1972.

Holotype. Zambia, Chowo Forest, Nyika Plateau, leg. M. Jellicoe 53, IV-1969 (BM!, isotype US!).

Description. Thallus subirregular laciniate, turning dusky green in the herbarium, fragments up to $4.3 \mathrm{~cm}$ diam., coriaceous, corticicolous; upper cortex 12.5-20.0 $\mu \mathrm{m}$ thick, algal layer 15.0-25.0 $\mu \mathrm{m}$ thick, medulla $100.0-155.0 \mu \mathrm{m}$ thick, lower cortex $15.0-25.0 \mu \mathrm{m}$ thick. Laciniae irregularly to dichotomously branched, $1.4-3.2 \mathrm{~mm}$ wide, imbricate, becoming crowded in the center, adnate to slightly elevate, adpressed to loose, with flat to slightly involute, subrounded to truncate apices, margins flat to slightly involute, crenate to irregular, incised, not lacinulate, axils oval to irregular. Upper surface smooth and continuous at the distal parts, becoming subrugose and transversally cracked at the center, laminal ciliary bulbs absent. Lacinulae absent, even marginal adventitious ones. Maculae absent. Cilia black to occasionally brown, apices simple $0.05-0.30(-0.70) \times$ ca. $0.03 \mathrm{~mm}$, with emerse bulbate bases $0.05-0.10(-0.15)$ $\mathrm{mm}$ wide, frequent throughout the margin spaced $0.05-0.10 \mathrm{~mm}$ from each other but becoming more prominent in the axils, absent or scarce at the apices of the laciniae. Soredia pustulae and isidia absent. Medulla white. Lower surface almost uniformly pale brown, except for some random dark brown parts, slightly shiny, smooth to subrugose, moderately rhizinate. Marginal zone brown to dark brown, indistinct from the center, slightly shiny, smooth, slightly papillate. Rhizinae pale brown to partially dark, occasionally with blackish apices, simple, without bulbate bases, $0.10-0.70 \times \mathrm{ca}$. $0.05 \mathrm{~mm}$, frequent, evenly distributed. Apothecia subconcave to concave or urceolate, adnate to substipitate, $0.3-7.2 \mathrm{~mm}$ diam., laminal to submarginal, margin smooth to irregularly subcrenate becoming retorted and fissured when old, ecoronate, amphithecia smooth to subrugose, without ornamentations. Disc dark brown, epruinose, imperforate, epithecium 10.0-15.0 mm high, hymenium 30.0-50.0 $\mu \mathrm{m}$ high, subhymenium 7.5-17.5 $\mu \mathrm{m}$ high. Ascospores subrounded to ellipsoid, 6.0-9.0 (-10.0) 

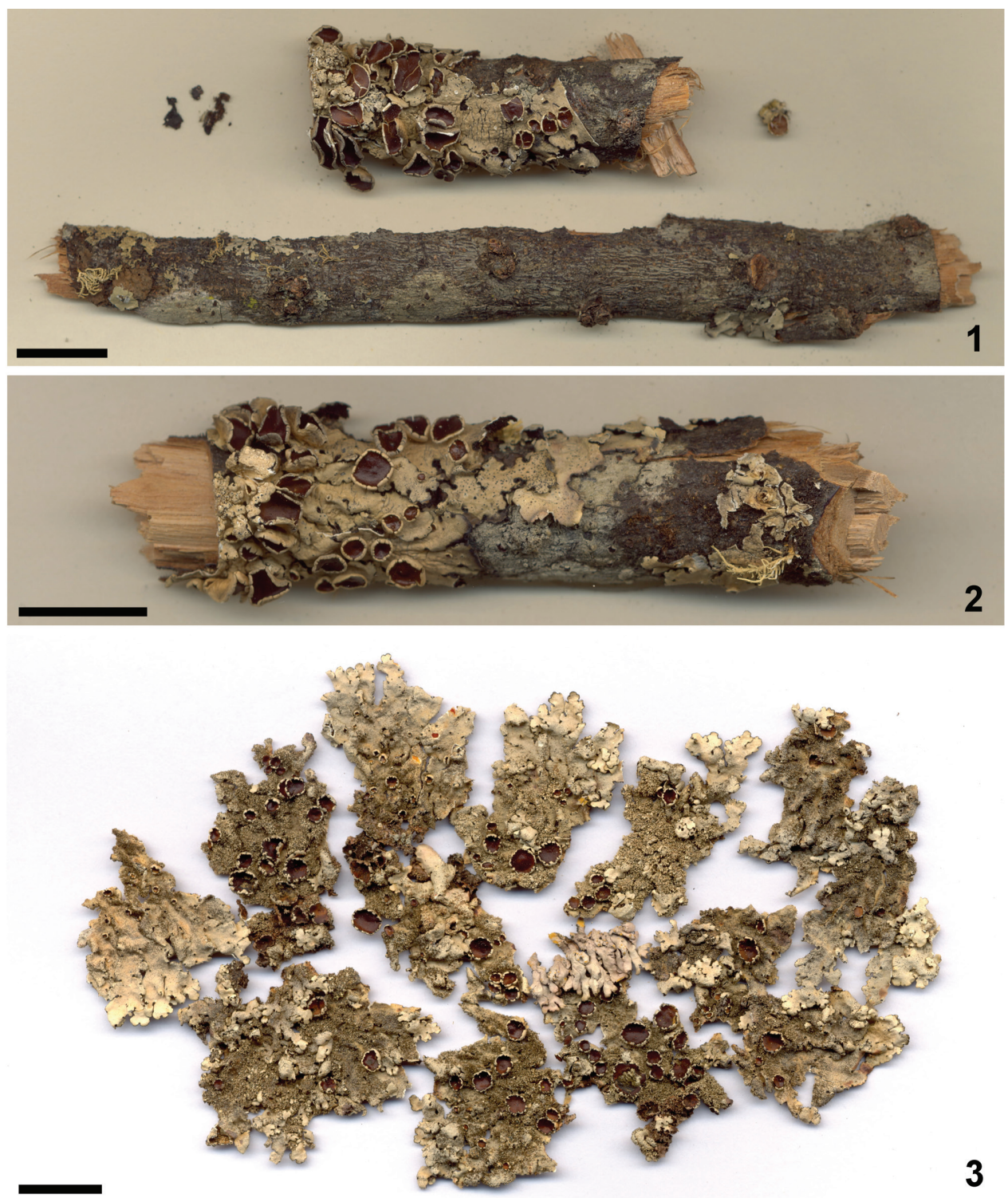

3

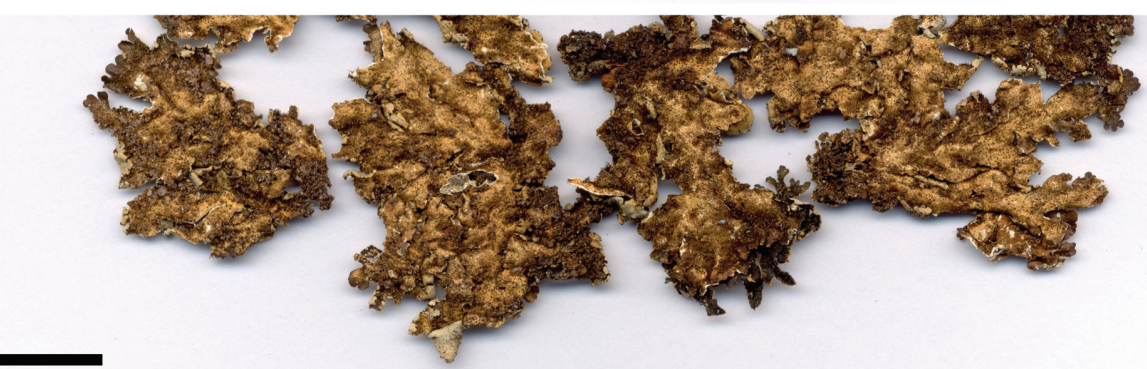

Figures I-4. Holotype of Bulbothrix chowoensis 2 Isotype of Bulbothrix chowoensis $\mathbf{3}$ Holotype of Bulbothrix cinerea 4 Detail of the lower side of the holotype. Scale bars $=1 \mathrm{~cm}$. 
$\times$ 4.5-6.0 mm, epispore ca. $1.0 \mathrm{~mm}$. Pycnidia laminal to submarginal, immerse, with black ostioles. Conidia weakly to evidently bifusiform, 5.0-7.0 $\times 0.75 \mu \mathrm{m}$.

Spot tests. upper cortex $\mathrm{K}+$ yellow, UV-; medulla $\mathrm{K}-, \mathrm{C}-, \mathrm{KC}+$ rose, $\mathrm{P}+$ reddish orange, UV-.

TLC/HPLC. cortical atranorin, medullary protocetraric and conprotocetraric acids (see also Hale 1972, 1976). Analysis made by Dr. John A. Elix showed also salazinic and consalazinic acids on the isotype. In view of the condition of the collection, I believe it is a possible contaminant from mixed fragments of other thalli, since they are much agglomerated.

Distribution. Africa: Mozambique, Zambia (Hale 1972, 1976).

Comments. The holotype (Fig. 1) and the isotype (Fig. 2) consist of two fragments; the original specimen was apparently separated in half. Both type fragments are in good condition, but are still attached to a small twig which is glued to a card, making it difficult to clearly see the lower cortex. Both fragments contain well-developed apothecia and many pycnidia with mature ascospores and conidia.

Compared to the original description (Hale 1972), the investigated type material showed some differences in the thallus anatomy. The thicknesses mentioned by Hale for the upper cortex $(14.0-18.0 \mu \mathrm{m})$, the algal layer $(10.0-15.0 \mu \mathrm{m})$, medulla $(70.0-90.0 \mu \mathrm{m})$ and lower cortex $(12 \mu \mathrm{m})$ are smaller than those found here, especially for the medulla. The ascospores found were slightly larger.

This is the only true species of Bulbothrix with medullary protocetraric acid currently known, since $B$. subinflata (Hale) Hale proved to be a Parmelinopsis species (Benatti and Marcelli 2010).

Although the ciliary bulbs of $B$. chowoensis are small and not as evident as in other species of the genus, they are noticeable even with the thickening of the marginal black line, and are even more easily seen when this line is brownish. The bulbs, even when subtle, have the typical anatomical structure containing idioblast cells and an oily substance (Hale 1975, Feuerer and Marth 1997, Benatti 2011).

Bulbothrix hypocraea (Vainio) Hale differs from $B$. chowoensis by the evidently maculate upper cortex, larger and more evident bulbate cilia, larger ascospores (8.0-14.0 $\mu \mathrm{m}$ long) and by the presence of medullary salazinic acid.

Bulbothrix setschwanensis (Zahlbruckner) Hale differs in having - like B. hypocrea - larger and more evident bulbate cilia, larger ascospores (12.0-19.0 $\mu \mathrm{m}$ long) and medullary salazinic acid.

Bulbothrix viatica Spielmann \& Marcelli differs by the coronate apothecia, common and constant occurrence of laminal ciliary bulbs, larger ascospores (12.0-18.0 $\mu \mathrm{m}$ long), variable coloration of the lower cortex and by the presence of medullary norstictic acid.

Bulbothrix regnelliana Jungbluth, Marcelli \& Elix differs by the coronate apothecia, the ascospores size $(8.0-12 ., 0 \mu \mathrm{m}$ long) and by the presence of medullary norstictic acid.

Bulbothrix subcoronata (Fée) Hale differs in by the black lower cortex with brown margins, coronate apothecia, and smaller ascospores $(5.0-7.5 \times 4.0-5.5 \mu \mathrm{m})$. 


\section{Bulbothrix cinerea Marcelli \& Kalb. Mitteilungen aus dem Institut für Allgemei- ne Botanik Hamburg 30/32: 127. 2002.}

Mycobank: MB 427200

Figures 3-4

Holotype. Brasil, Bahia, Serra do Tombador, between Mundo Novo and Morro do Chapéu, alt. 1000 m, leg. K. Kalb s.n., 18/20-VII-1980 (K. Kalb pers. herb. 20931!).

Description. Thallus sublinearly laciniate, turning dusky gray in the herbarium, fragments up to $3.8 \mathrm{~cm}$ diam., subcoriaceous, saxicolous; upper cortex 12.5-17.5 $\mu \mathrm{m}$ thick, algal layer 25.0-37.5 $\mu \mathrm{m}$ thick, medulla 62.5-75.0 $\mu \mathrm{m}$ thick, lower cortex 12.5-22.5 $\mu \mathrm{m}$ thick. Laciniae irregularly or in part anisotomically dichotomously branched, 0.4$1.6(-2.5) \mathrm{mm}$ wide, slightly imbricate becoming more crowded in the center, strongly adnate and very appressed, with flat, truncate to subtruncate apices, the margins flat, crenate to subcrenate or somewhat subirregular, entire to slightly incised, sometimes sublacinulate, the axils oval, upper surface smooth and continuous occasionally with irregular cracks in older parts, laminal cilia bulbs absent. Lacinulae marginal, adventitious, scarce, randomly appearing in old parts, short, flat, simple to furcate or irregularly branched, truncate, underside pale brown concolorous with the lower marginal zone, $0.2-1.5 \times$ $0.1-0.7 \mathrm{~mm}$. Maculae absent. Cilia black, without apices or with very brittle, simple and downward-bent apices, $0.05-0.40 \times \mathrm{ca} .0 .03 \mathrm{~mm}$, with semi-immerse to emerse bulbate bases $0.10-0.20(-0.30) \mathrm{mm}$ wide, frequently throughout the margins spaced ca. 0.05 $\mathrm{mm}$ from each other to occasionally contiguous, in small groups or solitary in the crenulations and axils, often reniform and withered, becoming absent or scarce at the apices of the laciniae. Soredia and pustulae absent. Isidia frequent, laminal, granular to smooth cylindrical \pm irregular, occasionally slightly flattened or somewhat dilated (but not inflated), straight, $0.05-0.30(-0.65) \times \mathrm{ca}$. $0.05-0.15(-0.30$ when dilated $) \mathrm{mm}$, simple to sometimes sparsely branched, erect, firm although brittle, quite shiny with brown or blackish apices, eciliate (sometimes swollen and resembling thick pycnidia, see comments). Medulla white. Lower surface almost uniformly pale brown, except for some darker marginal parts, shiny, smooth, slightly papillate, moderately rhizinate. Marginal zone brown to dark brown, almost indistinct from the center, shiny, 0.5-1.0 mm wide, smooth, papillate or slightly rhizinate. Rhizinae brown to dark brown, simple, generally with dark bulbate bases, $0.10-0.60 \times \mathrm{ca} .0 .05(-0.10) \mathrm{mm}$, frequent, evenly distributed. Apothecia subconcave to concave, adnate to substipitate, $0.3-3.7 \mathrm{~mm}$ diam., laminal, margin crenate to dentate and incised, coronate, the bulbs frequently interrupting the continuity of the margin leaving them lobulate, amphithecia smooth without ornamentations when young becoming gradually more isidiate and sometimes forming ciliary bulbs with progressing development. Disc light or meaty brown, epruinose, imperforate, epithecium 7.5-12.5 $\mu \mathrm{m}$ high, hymenium 45.0-55.0 $\mu \mathrm{m}$ high, subhymenium 25.0-32.5 $\mu \mathrm{m}$ high. Ascospores ellipsoid to oval, $10.0-13.5 \times 6.0-7.5(-8.5) \mu \mathrm{m}$, epispore ca. $0.5 \mu \mathrm{m}$. Pycnidia laminal (a lichenicolous fungus resembling pycnidia may occur on the isidia), immerse, with brown or black ostioles. Conidia weakly bifusiform, 5.0-6.0 × $1.0 \mu \mathrm{m}$. 
Spot tests. upper cortex K+ yellow, UV-; medulla K+ yellow $\rightarrow$ orange or light red, C-, KC-, P+ orange, UV-.

TLC/HPLC. cortical atranorin, medullary norstictic and connorstictic acids (see also Marcelli and Ribeiro 2002).

Distribution. South America: Brazil - Bahia (Marcelli and Ribeiro 2002) and Minas Gerais (Ribeiro 1998, Marcelli and Ribeiro 2002).

Additional specimen examined. Brazil, Minas Gerais State, Catas Altas Municipality, Serra do Caraça, Parque Natural do Caraça, on sun exposed rock at the trail at the edge of riparian, leg. M.P. Marcelli \& C. H. Ribeiro 31971, 09-IX-1997 (SP).

Comments. The holotype (Fig. 3) consists of several small fragments (between 0.5 and $4.0 \mathrm{~cm}$ diam.) in good condition, free of substrate, not being glued to a card voucher. The lower cortex is easily viewable. On most of the fragments there are several apothecia in various stages of maturation, but not all fragments have apothecia containing mature ascospores.

Until the discovery of this species, $B$. decurtata (Kurokawa) Hale was the only other known species of the genus that appeared to be obligatory saxicolous. In view of the very fragmentary condition of the analyzed material, $B$. cinerea seems to be a species whose thalli are very closely attached to the substrate and difficult to collect, as noted already by the authors (Marcelli and Ribeiro 2002).

The accentuated gray tinge of the thalli seen in B. cinerea is unusual among Parmeliaceae (Marcelli \& Ribeiro 2002). Its isidia also have some peculiarities. Their dark apices are somewhat bright in young stages and can, at this stage, be confused with laminal ciliary bulbs [like those found in specimens of B. ventricosa (Hale \& Kurokawa) Hale], parasitic fungi, or pycnidia.

Cross-sections of the isidia reveal, however, the typical anatomical structure: they are only covered by a thin dark "skin" [similar to the isidia of the saxicolous species B. decurtata (Kurokawa) Hale] and lack a compact cortex cover. This dark coverage is restricted to the apices of the isidia when they are mature.

Common among isidia on both specimens studied are large, globose, blackened structures about $0.10-0.30 \mathrm{~mm}$ wide. They are mainly visible in the more inflated isidia and might be of parasitic nature. Morphologically they are identical to laminal pycnidia, but conidia were not found in sections under the microscope.

As explained by the authors (Ribeiro and Marcelli 2002), B. cinerea tends to have marginal cilia without apices or with simple apices curved downward toward the substrate, leaving only the bulbs visible when casually observed from above. Sometimes scars or remnants of brittle apices can be observed. Several of the bulbs, however, notably those who developed in parts of the thallus unlikely to "anchor" it to the substrate, do not show any signs of apex development.

Bulbothrix isidiza (Nylander) Hale differs by being corticicolous with a more light tinged cortex, having laciniae twice as large as those of $B$. cinerea (2.0-5.5 mm wide), isidia that are never pycnidiate and not becoming swollen or lobulate, and having salazinic acid as medullary substance. 
Bulbothrix ventricosa also differs from $B$. cinerea by being corticicolous, having a lighter tinge with larger laciniae $(1.5-4.5 \mathrm{~mm}$ wide), never having pycnidiate isidia that are concolor to the cortex which do not become swollen or lobulate, and the often variable mottled colored lower cortex, as well as the fairly common presence of laminal ciliary bulbs.

Bulbothrix decurtata differs from $B$. cinerea by having both a black lower cortex and rhizinae, and salazinic acid as medullary substance. Although when undeveloped the isidia of both species are somewhat similar (curiously, only saxicolous species of the genus appear to form blackened isidia), its development is well differentiated. Isidia on $B$. cinerea grow larger and thicker, often appearing to be inflated (but not really pustular) or getting flattened acquiring an aspect similar to lobules. The isidia of $B$. decurtata are small and near always completely blackened, even in advanced stages of development. Pycnidia do not develop in the isidia of $B$. decurtata.

\section{Bulbothrix haleana Sérusiaux. The Bryologist 87(1): 2. 1984.} Mycobank: MB 106639

Figures 5-7

Holotype. Zaire, Massif du Kahuzi, un peu au nord de la piste du Kahuzi, sur le versant sud-ouest du mont, bloc rocheux (type porphyre) au ras du sol dans une lande à Erica bequaertii et Philippia benguelensis, alt. 2780 m., leg. J. Lambinon 71/Z/1356, 30-XII-1971 (LG!, isotype US!).

Description. Thallus subirregular to partially sublinearly sublaciniate, turning light dusky gray in the herbarium, fragments up to $3.6 \mathrm{~cm}$ diam., coriaceous, saxicolous; upper cortex 15.0-25.0 $\mu \mathrm{m}$ thick, algal layer 37.5-52.5 $\mu \mathrm{m}$ thick, medulla 42.5-80.0 $\mu \mathrm{m}$ thick, lower cortex $20.0-30.0 \mu \mathrm{m}$ thick. Laciniae irregularly ramified to occasionally dichotomously branched, (0.7-) $1.5-5.2 \mathrm{~mm}$ wide, slightly imbricate becoming partially crowded in the center, weakly adnate and loosely adpressed, with flat to involute, subrounded to subtruncate apices, the margins flat, smooth to crenate or partially irregular, entire to slightly incised, not lacinulate, the axils oval to irregular, upper cortex continuous, smooth to subrugose, occasionally with irregular cracks on older parts, laminal ciliary bulbs absent. Lacinulae absent, not even adventitious ones in older parts. Maculae punctiform, laminal, usually distinct but weaker in some parts. Cilia black or occasionally dark brown, with simple to occasionally furcate and partially downward-bent apices, $0.10-0.55(-1.00) \times 0.04-0.05 \mathrm{~mm}$, usually with emerse bulbate bases (0.05-) $0.10-0.15 \mathrm{~mm}$ wide but partially not bulbate (bulbs aborted?), sometimes the bulbs being taken along by the apices with the cilia growth, frequent along the margins spaced $0.05-0.20 \mathrm{~mm}$ from each other to rarely contiguous, solitary or in small groups in the crenulations and axils, usually absent or scarce in the apices of the laciniae and adjacent areas. Soredia, pustulae and isidia absent. Medulla white. Lower surface pale brown to cream colored, sometimes with small dark brown spots in the center, slightly shiny to opaque, smooth to partially subrugose, moderately 

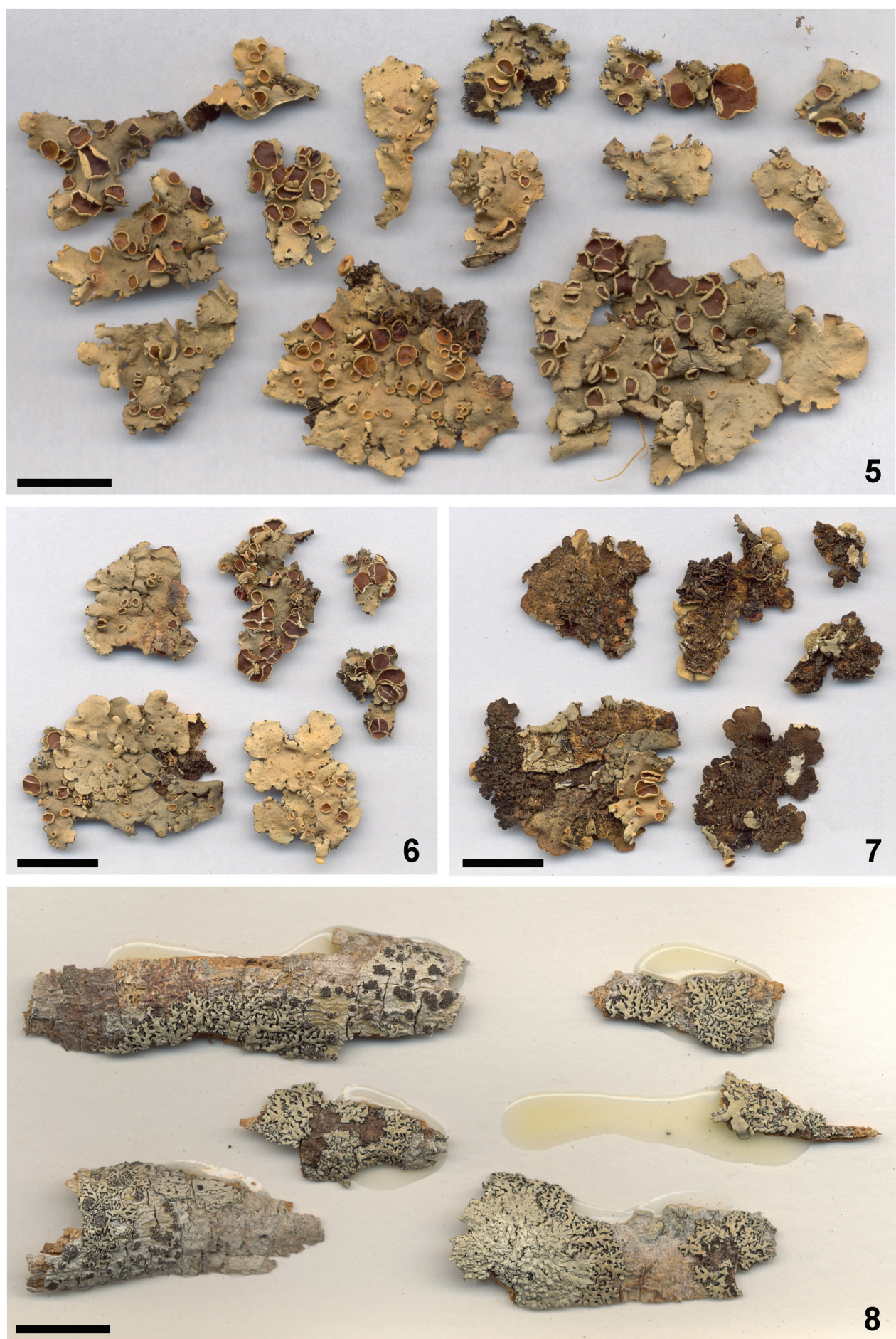

Figures 5-8. Holotype of Bulbothrix haleana 6 Isotype of Bulbothrix haleana 7 Detail of the lower side of the isotype 8 Holotype of Bulbothrix lordhowensis. Scale bars $=1 \mathrm{~cm}$. 
rhizinate up to the margins. Marginal zone indistinct from the center to slowly attenuate, pale brown to brown, opaque to slightly shiny, smooth, weakly to moderately rhizinate. Rhizinae light to dark brown or sometimes blackened, generally with whitish apices, simple, becoming sometimes furcate or irregularly branched, partially with bulbate bases or displaced bulbs, $0.10-0.70(-1.30) \times$ ca. $0.05-0.10 \mathrm{~mm}$, frequent to abundant, evenly distributed. Apothecia subplane to concave, sessile to adnate or substipitate, $0.2-6.3 \mathrm{~mm}$ diam., laminal to submarginal, margins smooth becoming subcrenate, ecoronate, amphithecium smooth becoming rugose, without ornamentations. Disc light to dark brown, epruinose, imperforate, epithecium 10.0-15.0 $\mu \mathrm{m}$ high, hymenium 32.5-45.0 $\mu \mathrm{m}$ high, subhymenium 15.0-22.5 $\mu \mathrm{m}$ high. Ascospores ellipsoid to oval or subglobose, (5.0-) 6.0-8.0 (-9.0) $\times(4.0-)$ 5.0-7.0 $\mu \mathrm{m}$, epispore ca. $1.0 \mu \mathrm{m}$. Pycnidia laminal, commonly on the distal parts of the laciniae, immersed, with black ostioles. Conidia bacilliform to weakly bifusiform, $5.0-8.0 \times 1.0 \mathrm{~mm}$.

Spot tests. upper cortex K+ yellow, UV-; medulla $\mathrm{K}+$ yellow $\rightarrow$ reddish orange, C-, $\mathrm{KC}-$, P+ orange, UV-.

TLC/HPLC. cortical atranorin, medullary norstictic and connorstictic acids (examined and confirmed by samples sent to Jack A. Elix; Sérusiaux 1984 mentioned medullary salazinic acid).

Distribution. Africa. Zaire (Sérusiaux 1984).

Comments. Both the holotype (Fig. 5) and the isotype (Figs. 6-7) are small fragments between 1.0 and $3.5 \mathrm{~cm}$ in diameter. Both are in good condition, only slightly damaged, and not glued to cards, which made the investigation of the lower cortex possible. Inside the packet are small envelopes, containing very small fragments and loose/detached apothecia.

Although the species was originally described as containing medullary salazinic acid, the substance confirmed by microchemical tests and chromatography was norstictic acid. It is the only species currently known within this chemical group with ecoronate apothecia.

Sérusiaux (1984) mentioned laciniae 1.0-3.0 mm wide, but the laciniae of the type material are larger, $1.5-5.0 \mathrm{~mm}$ wide. As for the ascospores, the measurements obtained were 6.0-9.0 $\times 4.0-7.0 \mu \mathrm{m}$, a little larger than in the original description.

Sérusiaux (1984) also described the upper cortex as "not maculate on young lobes, becoming more or less maculate elsewhere". I found that distal parts of the younger lobes show no signs of maculae, but in most of the thallus, especially the older parts, the maculae are punctiform and dense, like those observed in species such as B. hypocraea.

Most of the cilia present typical inflated bases, but it is not uncommon that cilia without inflated bases are occasionally found among groups of cilia with inflated bases. Interestingly, in some cilia the bulb is displaced from the base. However, it is hardly found above the first third of the cilia length. It is uncertain why some cilia have no bulbs; maybe they were aborted or maybe they are not formed until a later stage of development.

The lower cortex is almost entirely brown, and in a few small spots more restricted to the central portions of the thallus it becomes a little darker. Sérusiaux (1984) wrote 
that the cortex could become almost whitish in some parts, but due to colour change after longer stay in the herbarium it is difficult to confirm this assertion. Most of the rhizinae have basal or displaced bulbs.

Sérusiaux (1984) commented on the presence of black dots he supposed to be pycnidia, but he did not found sterigmata or conidia. In fact, conidia are difficult to find in the type material, but when they are found the size and shape is typical for the genus. At the first sight the pycnidia were taken for laminal ciliary bulbs or parasitic fungi, but this was proven to be incorrect.

Sérusiaux (1984) distinguished $B$. haleana from other species of the genus by the saxicolous habit, the light color of the lower surface and the small size of the ascospores. Bulbothrix bulbochaeta (Hale) Hale, B. chowoensis (Hale) Hale, B. confoederata (W. L. Culberson) Hale, and B. laevigatula (Nylander) Hale, which have also small ascospores ( $\leq 10 \mathrm{~mm}$ long), differ chemically and morphologically from B. haleana. Other Bulbothrix species containing medullary salazinic acid were differentiated by the author mainly by the larger ascospores, ranging from $8.0-12.0$ to $14.0-20.0 \mu \mathrm{m}$ long.

Bulbothrix haleana is morphologically similar to $B$. hypocraea, but can be distinguished by the corticicolous habit, ascospores size (6.0-8.0 vs. $8.0-14.0 \mu \mathrm{m}$ long), and medullary chemistry (norstictic acid vs. salazinic acid). There is some lower cortex tone difference between the types, but it may be due to the degree of medullary norstictic and salazinic acids oxidation. The holotype of $B$. hypocraea has more strongly bent cilia and is even more maculate, while the rhizinae of $B$. haleana appear to be more frequently bulbate. All other characters are similar.

Bulbothrix decurtata (Kurokawa) Hale differs by the more linear laciniae, an emaculate and quite fissured upper cortex, the formation of blackish small isidia, a predominantly black lower cortex and rhizinae without basal bulbs.

Bulbothrix cinerea Marcelli \& Kalb also has medullary norstictic acid, a similar pale brown lower cortex and cilia aspect, but differs from $B$. haleana by the sublinear and dichotomous branched laciniae, emaculate upper cortex, simple laminal isidia with brown or blackish apices, and by the coronate apothecia.

\section{Bulbothrix lordhowensis Elix. Mycotaxon 56(1): 231. 1995.}

Mycobank: MB 412620

Figure 8

Holotype. Australia, New South Wales, Lord Howe Island, along track to Mutton Bird Point, 31 $32^{\prime} 45^{\prime} \mathrm{S}, 159^{\circ} 05^{\prime} 00^{\prime E} \mathrm{E}, 60 \mathrm{~m}$ alt., dry lowland forest with basalt outcrops, on dead canopy branches, leg. J. A. Elix 32781, 21-VI-1992 (CANB!, isotypes $\mathrm{HO}$ and MEL).

Description. Thallus sublinearly to linearly laciniate, turning pale dusky green in the herbarium, fragments up to $2.2 \mathrm{~cm}$ diam., subcoriaceous, corticicolous; upper cortex $12.5-20.0 \mu \mathrm{m}$ thick, algal layer 15.0-22.5 $\mu \mathrm{m}$ thick, medulla 57.5-70.0 $\mu \mathrm{m}$ thick, lower cortex 15.0-22.5 $\mu \mathrm{m}$ thick. Laciniae dichotomously or trichotomously branched or oc- 
casionally slightly irregularly ramified, $0.3-0.6 \mathrm{~mm}$ wide, contiguous to occasionally imbricate or rarely crowded, adnate and appressed, with flat to slightly involute, subtruncate to truncate apices, the margins flat to subconvex, crenate to subirregular, entire to slightly incised and occasionally sublacinulate, the axils oval or irregularly shaped, upper cortex continuous and smooth, frequently with irregular cracks mainly on older parts, laminal ciliary bulbs common and frequent. Lacinulae scarce, marginal and adventitious, short, flat, $0.10-0.60 \times 0.05-0.20 \mathrm{~mm}$, simple or irregularly branched, truncate or sometimes acute, underside concolorous with the lower marginal zone. Maculae absent (not to be confused with marks left by detachment of the isidia, sometimes deep, exposing the medulla). Cilia black or occasionally brown, with simple to furcate or trifurcate apices, sometimes subdichotomously branched in the axils, $0.05-0.25(-0.40) \times \mathrm{ca} .0 .03 \mathrm{~mm}$, with semi-immerse to emerse bulbate bases ca. $0.05(-0.10) \mathrm{mm}$ wide, contiguous along the margins or up to $0.5 \mathrm{~mm}$ spaced from each other, usually absent or scarce on the apices of the laciniae. Soredia and pustulae absent. Isidia frequent, laminal, granular to short smooth cylindrical, straight, $0.05-0.10(-0.20) \times$ ca. $0.05 \mathrm{~mm}$, simple to sometimes sparsely branched, erect, firm to caducous, darkened and with dark brown apices, eciliate. Medulla white. Lower surface black, shiny, smooth to subrugose, densely rhizinate with some open parts. Marginal zone attenuate, brown, shiny, 0.3-0.5 mm wide, smooth, generally rhizinate. Rhizinae black, sometimes with brown apices, initially simple becoming furcate and then dichotomous, apparently without bulbs, $0.10-0.40 \times \mathrm{ca}$. $0.03-0.05$ $\mathrm{mm}$, abundant, evenly distributed. Apothecia and pycnidia not found.

Spot tests. upper cortex K+ yellow, UV-; medulla K+ yellow $\rightarrow$ orange, C-, KC-, P+ orange, UV-.

TLC/HPLC. cortical atranorin and chloroatranorin, medullary norstictic acid and two unknown substances (Elix 1995).

Distribution. Oceania. Australia (Elix 1995).

Comments. The holotype (Fig. 8) consists of six small fragments in good condition, along with a small and fragile fragment. Isidia are or were present on all specimens; the latter can be identified by the marks that are left where the isidia broke off. A fragment is covering a Sarcographa specimen, while another fragment is partially covered by a small, sorediate Physcia specimen.

There are frequent laminal ciliary bulbs in the holotype. Part of the observed laminal bulbs were first interpreted as poorly developed pycnidia or even parasitic fungi, which has been proven wrong. Besides being generally small in size also in the margins, some of the laminal bulbs are poorly developed.

This is one of the species with the narrowest laciniae in the genus, barely exceeding $0.5 \mathrm{~mm}$ in width. The cilia are evidently bulbate, with very small bulbs. Bulbs were not seen in the rhizinae, and if they occur, they should be rare and very subtle. The isidia are very small and appear as unornamented, darkened grains. When detached, they can leave strong marks, resembling spilled medulla that comes out through the cortex. They are easily distinguishable from maculae.

Bulbothrix queenslandica (Elix \& Stevens) Elix (MEL!, US!), differs by the larger laciniae (0.5-1.5 mm wide), cortical maculae, concolorous and ciliate isidia, and the 
absence of medullary substances. Bulbothrix pigmentacea (Hale) Hale probably has only small amounts of gyrophoric acid, and random spots of a K- reddish pigment in the medulla, rhizinae and lower cortex. For comparison of B. lordhowensis with $B$. queenslandica and B. pigmentacea (Hale) Hale, see also Elix (1995).

Among the isidiate species with medullary norstictic acid, B. ventricosa (Hale \& Kurokawa) Hale differs by the larger laciniae (1.0-5.0 mm wide) with rounded apices, less frequent cilia and rhizinae with simple apices, larger and simple, concolorous isidia (which leave no such conspicuous marks as in B. lordhowensis), and by the frequently mottled coloration of the lower cortex. Bulbothrix cinerea Marcelli \& Kalb differs from $B$. lordhowensis by being saxicolous, having larger laciniae $(0.5-2.5 \mathrm{~mm}$ wide), and lacking laminal ciliary bulbs. It has cilia and rhizinae with simple apices and a pale brown lower cortex.

Bulbothrix subtabacina (Elix) Elix (MEL!, CANB!) has larger laciniae (0.5-1.0 mm wide), a maculate and very brittle upper cortex, concolorous isidia, and medullary salazinic acid. Bulbothrix tabacina (Montagne \& Bosch) Hale (L!, PC!) has even larger (1.0-5.0 mm wide), irregularly branched laciniae with more rounded apices, cilia and rhizinae with simple apices, and also contains medullary salazinic acid.

\section{Bulbothrix regnelliana Jungbluth, Marcelli \& Elix. Mycotaxon 104: 58. 2008.} Mycobank: MB 511169

Figures 9-10

Holotype. Brazil, São Paulo State, São José do Rio Preto Municipality, $20^{\circ} 49^{\prime} \mathrm{S}, 49^{\circ} 22^{\prime} \mathrm{W}$, $489 \mathrm{~m}$ alt., on palm tree trunk in open field, D.F. Peralta 2325, 09-IV-2004 (SP!, isotype B!).

Description. Thallus subirregular sublaciniate, dusky gray in herbarium, fragments up to $4.6 \mathrm{~cm}$ diam., subcoriaceous, corticicolous; upper cortex 12.5-17.5 $\mu \mathrm{m}$ thick, algal layer 20.0-25.0 $\mu \mathrm{m}$ thick, medulla 75.0-92.5 $\mu \mathrm{m}$ thick, lower cortex $12.5-17.5 \mu \mathrm{m}$ thick. Laciniae irregularly ramified to occasionally anisotomically dichotomously branched, (1.0-) 1.6-2.5 (-3.7) mm wide, imbricate becoming crowded in the center, weakly adnate to loose and ascending, with flat to involute, subrotund apices, the margins flat to involute frequently giving the laciniae a subcanaliculate aspect, crenate to subirregular, entire to irregularly incised, not lacinulate, the axils oval to irregular, upper cortex continuous with rare, random irregular fissures, smooth, laminal ciliary bulbs absent. Lacinulae absent, not even marginal adventitious ones present. Maculae absent. Cilia black, apices frequently absent to less commonly simple and short, $0.05-0.25 \times$ ca. $0.03 \mathrm{~mm}$, with emerse bulbate bases (0.05-) 0.10-0.35 $\mathrm{mm}$ wide, frequently along the margins in the crenulations and axils of the laciniae spaced $0.05-0.10 \mathrm{~mm}$ from each other, occasionally becoming contiguous, solitary or in small groups, becoming absent or scarce at the apices of the laciniae and adjacent parts. Soredia, pustulae and isidia absent. Medulla white. Lower cortex pale brown to brown, sometimes appearing to be darker in some parts due to groups of dark 

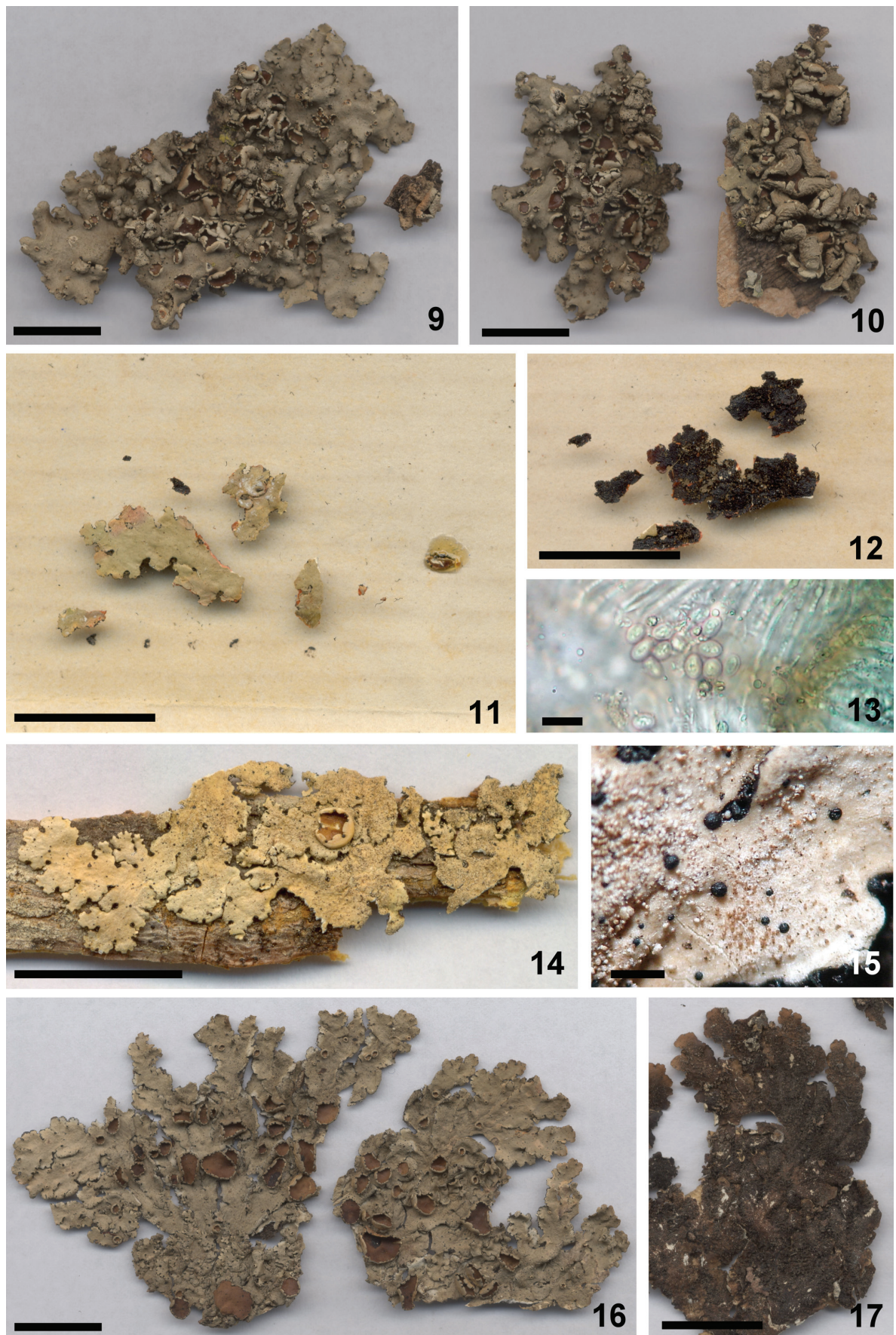

Figure 9-I7. Holotype of Bulbothrix regnelliana 10 Isotype of Bulbothrix regnelliana II Lectotype of Bulbothrix subcoronata $\mathbf{2}$ Detail of the lower side of the lectotype $\mathbf{1 3}$ Ascospores from the apothecium on fig. 11 I 4 Lectotype of Bulbothrix ventricosa 15 Detail of the laminal bulbs amidst the isidia 16 Holotype of Bulbothrix viatica 17 Detail of the lower side of the holotype. Scale bars $=1 \mathrm{~cm}(\mathbf{9}, \mathbf{1 0}, \mathbf{1 1}, \mathbf{1 2}, \mathbf{1 4}, \mathbf{1 6}$, 17), $1 \mathrm{~mm}$ (15), and $10 \mu \mathrm{m}$ (13). 
rhizinae, opaque, rugose, moderately to densely rhizinate. Marginal zone brown to pale brown, not distinct from the center, opaque to slightly shiny, rugose or weakly venate, papillate, becoming slightly rhizinate towards the center. Rhizinae brown to pale brown, occasionally dark, black or with whitish apices on random parts, simple or rarely irregularly branched, generally with blackish bulbate bases of dislocate bulbs, $0.10-0.50(-0.80) \times 0.03-0.10 \mathrm{~mm}$, frequent to abundant, commonly agglutinated, evenly distributed. Apothecia concave to urceolate, adnate to substipitate, $0.3-7.5 \mathrm{~mm}$ diam., laminal, margins crenate becoming deeply crenate, fissured and folded as they age, coronate (bulbs irregularly appearing in the crenulations), amphithecia smooth to rugose without ornamentations. Disc brown, epruinose, imperforate, epithecium 10.0-15.0 mm high, hymenium $25.0-40.0 \mu \mathrm{m}$ high, subhymenium $20.0-30.0 \mu \mathrm{m}$ high. Ascospores ellipsoid to oval, (7.0-) 8.0-12.0 (-14.0) × 4.0-7.0 (-8.0) $\mu \mathrm{m}$, epispore ca. $1.0 \mu \mathrm{m}$. Pycnidia frequent, submarginal to subapical or sometimes laminal, immerse, with black ostioles; conidia bacilliform to weakly or distinctly bifusiform, (4.0-) 5.0-7.5 (-9.0) × $1.0 \mu \mathrm{m}$.

Spot tests. upper cortex K+ yellow, UV-; medulla $\mathrm{K}+$ yellow $\rightarrow$ orange or light red, C-, KC-, P+ orange, UV-.

TLC/HPLC. cortical atranorin, medullary norstictic acid and four unknown substances (see also Jungbluth 2006, Jungbluth et al. 2008).

Distribution. South America. Brazil: São Paulo (Jungbluth 2006 as B. subcoronata, Jungbluth et al. 2008). Here is reported for Paraguay, Argentina, and Brazilian States of Minas Gerais and Rio Grande do Sul.

Additional specimens examined. Paraguay, Paraguarí, Parque Nacional Ybycuí, along road/trail to Salto Mbocaruzú on Rio Corrientes, ca. $200 \mathrm{~m}$, ca. $26^{\circ} 05^{\prime} \mathrm{S}$, $56^{\circ} 53^{\prime} \mathrm{W}$, dry Forest and extensive sandstone outcrops in cerrado, leg. W.R. Buck 12006a, 6-X-1984 (NY). Argentina, Corrientes, Depto. Capital, $500 \mathrm{~m}$ de tuta 12, camino a Santa Ana, em quebranchal, leg. L. Ferraro 1287, 05-VI-1978 (US). Idem, Depto. Esquina, $10 \mathrm{~km} \mathrm{~S}$ de ruta 126, camino de Tres Bocas a Paso Yunque, leg. A. Krapovickas 28074, 13-III-1975 (US). Idem, Missiones, San Ignacio, pastoreo Grande, em bosque despejado, sobre ramas de Astronium balansae y Helietta cuspidata, 290 m, leg. J. E. Montes 10060 pr. p., 20-III-1956 (US). Brasil, Minas Gerais State, Catas Altas Municipality, Serra do Caraça, Parque Natural do Caraça, on tree trunk at the foot of the Morro do Calvário at the side of the hotel, leg. M.P. Marcelli \& A.E. Luchi 29654, 10-XI-1995 (SP). Idem, São Paulo State, Serra Negra Municipality, Alto da Serra, near the television tower, on small tree twig on the edge of the illuminated and humid mountainous forest, leg. M.P. Marcelli, O. Yano \& A.B. Carvalho 22703, 05IV-1993 (SP). Idem, Santa Rita do passa Quatro Municipality, Vassununga farm, km 259 of the Anhanguera highway, $760 \mathrm{~m}$ alt., transition from cerrado to cerradáo, on thin twig, leg. M.P. Marcelli \& B. L. Morretes 16057, 27-IX-1978 (SP). Idem, Rio Grande do Sul State, Esmeralda Municipality, Estação Ecológica Aracuri, on cortex of Schinus polygamus, $920 \mathrm{~m}$ alt. leg. M. Fleig 1830, 12-XII-1982 (ICN).

Comments. The holotype (Fig. 9) and the isotype (Fig. 10) consist of two fragments in good condition, free of substrate, not glued to the voucher card, which made 
the observation of the characters of the lower cortex possible. Both have numerous apothecia, although it is difficult to find ascospores (hymenia often without asci).

Several authors determined specimens of B. regnelliana Jungbluth, Marcelli \& Elix as B. subcoronata (Müller Argoviensis) Hale or B. viatica Spielmann \& Marcelli (e.g. Eliasaro 2001, Ribeiro 1998). These three species form a closely related group, in which the species are distinguished mainly by the color of the lower cortex, the size of ascospores and the presence or absence of laminal ciliary bulbs.

Although Jungbluth (2006) made an attempt to relate the shape of apothecia with the size of the ascospores in order to separate the species with norstictic acid, a close examination of the material of $B$. subcoronata, $B$. regnelliana and $B$. viatica demonstrated that this is not a reliable character for the species separation due to character overlap. In fact there are specimens interpreted as B. subcoronata with ascospores ca. 7.0-12.0 $\mathrm{mm}$ long (Hale 1976, Fleig 1985) and others with ascospores 10.0-20.0 mm long (Marcelli1993, Eliasaro 2001, Ribeiro 1998).

Based on the color of the lower cortex and the ascospore size, the material examined by Hale (1976), which was described as $B$. subcoronata, should probably belong to $B$. regnelliana, as assumed by Jungbluth et al. (2008). It is also possible that the material examined by Fleig (1985), described with ascospores $\leq 10 \mathrm{~mm}$, belongs to $B$. regnelliana.

In fact, the type specimen of $B$. subcoronata has a shiny black lower cortex with a well defined brown marginal zone, and a single, coronate apothecium, containing very small ascospores $(5.0-7.5 \times 4.0-5.5 \mu \mathrm{m})$. Bulbothrix subcoronata is further distinguished from B. regnelliana by the smaller width of the laciniae (ca. $0.5-1.0 \mathrm{~mm}$ ), the more frequent marginal cilia often with simple apices, and the retrorse rhizinae on the amphithecium of the apothecia.

Bulbothrix viatica and B. regnelliana have several characteristics in common, which lead to the hypothesis that they were synonymous. Some specimens with overlapping characters were found; this concerned the absence of laminal ciliary bulbs, marginal cilia with and without apex, a brown lower cortex with small dark spots and ascospores $10.0-14.0 \mu \mathrm{m}$ long. However, when analyzing the characteristics of the specimens, verifying the collection sites and comparing the material side by side, a correlation of small features was noticed that include the total absence of laminal ciliar bulbs, an emaculate upper cortex, cilia often without apices, a strictly brown lower cortex and ascospores usually $\leq 12 \mu \mathrm{m}$ long in $B$. regnelliana. which are apparently constant and related to the possible geographic distribution of the species. We therefore decided not to put them into synonymy. The region of the Tropic of Capricorn seems to represent the northern limit of distribution for B. regnelliana, while the latitude of Rio Grande do Sul State in Brazil may represent the southern limit of distribution for B. viatica. Thus, there is a common area of occurrence for both. Also some very few specimens mentioned (Ribeiro 1998) with large ascospores, that are know only from the north of Minas Gerais State, also in Brazil, that might represent an undescribed taxa maybe overlapping with the distribution of $B$. viatica.

Bulbothrix ventricosa (Hale \& Kurokawa) Hale differs from B. regnelliana by having the same characteristics as B. viatica, and the presence of maculae as well as laminal 
isidia. The coloration of the lower cortex shows an even more frequent mixture variation (i.e., much more varied mixes of black and brown tones) in $B$. ventricosa than in B. viatica.

Bulbothrix hypocraea (Vainio) Hale differs by the densely maculate upper cortex, marginal cilia with simple apices, ecoronate apothecia and medullary salazinic acid.

Bulbothrix continua (Lynge) Hale differs by the sublinear and dichotomous laciniae, abundant and contiguous bulbate cilia with long apices bent downwards, rhizinae without basal bulbs, ecoronate apothecia and medullary salazinic acid. Bulbothrix lintelocarpa Marcelli is similar to $B$. continua, but has narrower laciniae (0.3-0.5 mm wide), simple to branched rhizinae, flat apothecia straining over the laciniae, and slightly larger ascospores 10.0-15.0 × 6.5-8.0 $\mu \mathrm{m}$.

Bulbothrix setschwanensis (Zahlbruckner) Hale differs by the frequent marginal cilia usually with simple apices, rhizinae without basal bulbs, ecoronate apothecia with larger ascospores 12.0-19.0 $\mu \mathrm{m}$ long, and medullary salazinic acid.

Relicina subabstrusa (Gyelnik) Hale (Hale 1975, Elix 1996) differs by having cortical usnic acid, laciniae more linear, cilia regularly with apices and not only restricted to the axils, and apothecia with bulbs or retrorse rhizinae on the amphithecium (as in $B$. subcoronata) containing smaller ascospores $(7.0-8.0 \times 4.0-5.0 \mu \mathrm{m})$.

\section{Bulbothrix subcoronata (Müller Argoviensis) Hale. Phytologia 28: 481. 1974.} Mycobank: MB 341614

Figures 11-13

Basionym. Parmelia subcoronata Müller Argoviensis. Revue Mycologique: 135. 1887.

Holotype. South America, place and collector unknown (G!, holotype).

Description. Thallus subirregularly to almost sublinearly sublaciniate, turning dusky green in the herbarium, fragments up to $1.2 \mathrm{~cm}$ diam., submembranaceous, corticolous (anatomy not observed in view of the scarce material). Laciniae anisotomically dichotomously branched, contiguous, $0.4-1.0 \mathrm{~mm}$ wide, weakly adnate and apparently loosely adpressed, with flat, truncate to subtruncate apices, the margins flat, slightly sinuous to subcrenate, entire, not lacinulate, the axils oval, upper cortex continuous and smooth, laminal bulbate cilia absent. Lacinulae absent, not even marginal adventitious ones. Maculae absent. Cilia black, usually with simple to rarely lacking apices, short, occasionally downward-bent, 0.05-0.40 (-0.60) × ca. $0.03 \mathrm{~mm}$, with emerse bulbate bases $0.05-0.10(-0.15) \mathrm{mm}$ wide, frequently along the margins in small groups in the crenulations and axils of the laciniae, spaced $0.05-0.15 \mathrm{~mm}$ from each other, becoming absent or scarce only at the apices of the laciniae. Soredia, pustulae and isidia absent. Medulla white (but tainted by the degenerated medullary acid). Lower surface black, shiny, smooth, papillate to slightly rhizinate. Marginal zone brown, attenuate, up to $0.5 \mathrm{~mm}$ wide, shiny, smooth, naked to papillate, becoming occasionally slightly rhizinate in the transition for the center. Rhizinae black, simple, commonly with subtle to conspicuous bulbate bases, $0.10-0.50 \times 0.02-0.05 \mathrm{~mm}$, fre- 
quent, randomly grouped. Apothecia (only one present) subplane, $2.1 \mathrm{~mm}$ diam., apparently sessile and laminal, margins smooth, coronate (with few bulbs), amphithecia smooth with some bulbate retrorse rhizinae. Disc brown, epruinose, imperforate, epithecium 5.0-12.5 mm high, hymenium 37.5-45.0 $\mu \mathrm{m}$ high, subhymenium 17.5-25.0 $\mu \mathrm{m}$ high. Ascospores rounded to subellipsoid, 5.0-7.5 × 4.0-5.5 $\mu \mathrm{m}$, epispore ca. 0.5 $\mu \mathrm{m}$. Pycnidia not found.

Spot tests. upper cortex K+ yellow, UV-; medulla $\mathrm{K}+$ yellow $\rightarrow$ orange or light red, C-, KC-, P+ yellowish orange, UV-.

TLC/HPLC. cortical atranorin, medullary norstictic acid (see also Hale 1976).

Distribution. Asia: India (Sinha and Singh 1986). South America: Argentina (Hale 1976, Calvelo and Liberatore 2002), Paraguay and Brazil: GO, MT, RJ (Hale 1976), PA (Brako et al. 1985), RS (Fleig 1985), SP (Marcelli 1993, Jungbluth 2006), MG (Ribeiro 1998) and PR (Eliasaro 2001).

Comments. The holotype of B. subcoronata (Fig. 11) consists merely of four very small fragments, only one being a whole laciniae, with the distal and proximal portions intact. Due to the very poor condition of the specimen it is difficult to describe it accurately, since many of the characters could not be observed. There is only a third of a mature apothecium left, glued to the card voucher. The medulla, which probably was white, is stained with a reddish brown tinge probably due the degeneration of norstictic acid. The hymenium of the single apothecium is brownish and contains few ascospores. Most asci contain only a shapeless mass. It was necessary to totally crush a cross section of the apothecium to observe the highest possible number of ascospores, because almost none emersed from asci when a simple section was put under the microscope (which is a quite common problem in specimens of this genus).

For many years, Bulbothrix specimens without vegetative propagation containing medullary norstictic acid with wider laciniae, a brown lower cortex and larger ascospores were identified as B. subcoronata. Recently Jungbluth et al. (2008) and Spielmann and Marcelli (2008) proved that they actually belong to different species, $B$. regnelliana and B. viatica. Unlike the descriptions found in Hale (1976), Fleig (1985), Marcelli (1993), Ribeiro (1998), Eliasaro (2001), Jungbluth (2006) but in agreement with the original diagnosis (Müller Argoviensis 1887), the ascospores of B. subcoronata are very small, being among the smallest in the genus. Müller Argoviensis (1887) described the species separating it from Parmelia tiliacea by the shape and color of the laciniae, shape of the apothecium and the small subglobose ascospores "ca. $5 \mu \mathrm{m}$ long". Among the 35 ascospores found in good condition, the minimum length was $5 \mu \mathrm{m}$ and only two slightly exceeded $7.0 \mu \mathrm{m}$ long. In his remarks, Hale (1976) mentioned that Müller Argoviensis (1887) had cited ascospores with ca. $5 \mu \mathrm{m}$ long, but that all the specimens he studied had larger ascospores.

In the holotype of B. subcoronata the laciniae are sublinear and quite narrow, with subtruncate apices $0.5-1.0 \mathrm{~mm}$ wide, while other specimens at first suspected to belong to $B$. subcoronata referred to the species have larger, more subirregular laciniae with subrounded apices, usually $1.0-4.5 \mathrm{~mm}$ wide. 
Apparently, B. subcoronata is a very rare species known only from the type. Since the original description mentions only South America as information for locality, it is impossible to give more precise location information.

Bulbothrix viatica Spielmann \& Marcelli can be differentiated by the larger laciniae (1.0-4.5 mm wide) with rounded apices, lower surface with variable colors tending to mixtures of brown with black, common occurrence of laminal ciliary bulbs, and by the larger ascospores (10.0-) 12.0-18.0 × 7.0-10.0 $\mu \mathrm{m}$.

Bulbothrix regnelliana Jungbluth, Marcelli \& Elix can be distinguished by the same characteristics (except that it do not form laminal ciliary bulbs), and by the ascospores 8.0-12.0 × 4.0-8.0 $\mu \mathrm{m}$. Bulbothrix ventricosa (Hale \& Kurokawa) Hale can also be differentiated by the same upper and lower cortex and ascospores characteristics of $B$. viatica, and additionally by the cortical maculae and flaminal isidia.

\section{Bulbothrix ventricosa (Hale \& Kurokawa) Hale. Phytologia 28(5): 481.1974. Mycobank: MB 341620}

Figures 14-15

Basionym. Parmelia isidiza var. domingensis Vainio. Annales Academiae Scientarum Fennicae 6A(7): 17. 1915.

Synonym. Parmelia ventricosa Hale \& Kurokawa. Contributions from the United States National Herbarium 36: 140. 1964. [nom. nov. for Parmelia isidiza var. domingensis Vainio]

Lectotype. Dominican Republic, Santo Domingo, La Cumbra, ad corticem arboris, leg. C. Raunkiaer 492, 09-IV-1906 (TUR-V!, duplicate C).

Description. Thallus sublinearly to subirregularly laciniate to sublaciniate, tuning dusky green in the herbarium, up to $8.7 \mathrm{~cm}$ diam., subcoriaceous to submembranaceous, corticicolous or ramulicolous; upper cortex 12.5-15.0 $\mu \mathrm{m}$ thick, algal layer 20.0-32.5 $\mu \mathrm{m}$ thick, medulla 52.5-67.5 $\mu \mathrm{m}$ thick, lower cortex 15.0-22.5 $\mu \mathrm{m}$ thick. Laciniae anisotomically dichotomously branched to irregularly ramified, (0.7-) 1.5-4.5 $\mathrm{mm}$ wide, contiguous to occasionally slightly imbricate in the center, weakly adnate and loosely adpressed, with flat to slightly involute, subtruncate to subrounded apices, the margins flat to slightly involute, crenate to subirregular, entire to slightly incised, rarely sublacinulate, axils oval, upper cortex usually continuous to irregularly fissured on older parts, smooth to subrugose, laminal ciliary bulbs common, scarce to abundant, usually frequent, rarely absent, mainly on young distal or less isidiate parts. Adventitious marginal lacinulae scarce on older parts, short, $0.2-0.5 \times 0.1-0.2(-0.3) \mathrm{mm}$, plane, simple or irregularly branched, apices truncate, lower side concolorous with the lower marginal zone. Maculae weak to distinct, punctiform to effigurate, laminal or in the amphithecia of the apothecia. Cilia black to occasionally whitish, with simple, frequently downward-bent, sometimes missing apices, $0.05-0.35 \times$ ca. $0.03 \mathrm{~mm}$, with emerse bulbate bases $0.05-0.15(-0.35) \mathrm{mm}$ wide, frequent along the margins in the crenulations and axils of the laciniae, spaced $0.05-0.10 \mathrm{~mm}$ from each other, some- 
times becoming contiguous, solitary or in small groups, becoming absent or scarce at the apices of the laciniae and some parts of the margins. Soredia and pustulae absent. Isidia frequent to abundant, laminal, granular to short smooth cylindrical, straight, $0.05-0.15(-0.25) \times$ ca. $0.05 \mathrm{~mm}$, simple to partially slightly ramified, erect, firm to slightly caducous, concolorous but partially with pale e brown apices, eciliate. Medulla white. Lower surface black with small dark brown spots, black mixed with brown in variable intermediary levels to entirely brown, shiny, smooth to rugose, partially venate, moderately rhizinate except by the margins. Marginal zone pale brown to brown or black, attenuate or indistinct from the center, shiny, $0.5-4.0 \mathrm{~mm}$ wide, smooth to subrugose, naked becoming rhizinate or papillate towards the center. Rhizinae black to brown, sometimes with whitish apices, simple, partially with bulbate bases, 0.05-0.30 $(-0.40) \times 0.03-0.05 \mathrm{~mm}$, frequent, evenly distributed. Apothecia subplane to concave, adnate, $0.3-4.2 \mathrm{~mm}$ diam., laminal, margins crenate, coronate (bulbs appearing in the crenulations), amphithecium smooth without ornamentations. Disc brown, epruinose, imperforate, epithecium 7.5-10.0 $\mu \mathrm{m}$ high, hymenium 65.0-75.0 $\mu \mathrm{m}$ high, subhymenium 25.0-37.5 $\mu \mathrm{m}$ high. Ascospores ellipsoid to oval, 11.0-20.0 × 7.0-10.0 (-11.5) $\mu \mathrm{m}$, epispore 1.0-1.5 $\mu \mathrm{m}$. Pycnidia (not found on type) laminal, immerse, with brown to black ostioles; conidia bacilliform to weakly bifusiform 5.0-7.0 x 1.0 $\mu \mathrm{m}$.

Spot tests. upper cortex K+ yellow, UV-; medulla K+ yellow $\rightarrow$ orange or light red, C-, KC-, P+ orange, UV-.

TLC/HPLC. cortical atranorin and chloroatranorin, medullary norstictic and connorstictic acids (examined by Jack A. Elix; see also Hale 1976, Hale and Kurokawa 1964).

Distribution. Asia: Thailand (Papong et al. 2007). Africa: South Africa (Hale 1976, Hale and Kurokawa 1964), Kenya (Swinscow and Krog 1988). North America: Mexico (Hale 1976, Hale and Kurokawa 1964). Central America and Caribbean: Costa Rica, Panama (Hale 1976), Dominican Republic (Vainio 1915, Hale 1976, Hale and Kurokawa 1964). South America: Venezuela (Hale 1976, López-Figueiras 1986, Marcano et al. 1996) and Brazil: Minas Gerais (Ribeiro 1998), São Paulo (Ribeiro 1998, Jungbluth 2006), Pará (Brako et al. 1985) and Paraná (Eliasaro 2001, Eliasaro and Adler 1997).

Additional specimens examined. Mexico, open pasture, scattered cactus and Acacia, elev. $1240 \mathrm{~m}, 9 \mathrm{~km}$ E of Jalapa, along highway 140, on Opuntia sp., leg. M.E.Hale \& T.R.Soderstrom 19389, 13-III-1960 (DUKE). Dominican Republic, La Vega, $4.7 \mathrm{~km} \mathrm{~S}$ of Constanza, then $8 \mathrm{~km}$ toward Pinar Parejo, moist broadleaf forest along road, 6150 ft., leg. R. C. Harris 14784E, 27-IV-1982 (NY). Venezuela, Táchira, Vía Rubio, Bramón, 800-1100 m, leg. M. E. Hale \& M. López-Figueiras 45727a, 24III-1975 (US). Bolivia, Santa Cruz, Florida, Santa Rosa de Lima, Quebrada Del Crestón, $5 \mathrm{~km}$ E of Santa Rosa, $17^{\circ} 52^{\prime} \mathrm{S}, 64^{\circ} 15^{\prime} \mathrm{W}, 1470 \mathrm{~m}$, leg. M. Salidas et al. 4370b, 3-VII-1996 (NY). Uruguay, Rocha, La Esmeralda (route 9, 280.5 km), on Acacia sp., $34^{\circ} 12^{\prime}$ S, 5352'W, 800-1100 m, leg. A. Mones s.n., 25-V-1986 (US). Brazil, Pará State, Serra do Cachimbo, $842 \mathrm{~km}$ N of Cuiabá on Cuiabá-Santarém highway (BR$163)$, ca. $8^{\circ} 45^{\prime} \mathrm{S}, 54^{\circ} 57^{\prime} \mathrm{W}$, ca. 350-500 m, mature Forest along stream on sandy soil with deep humus and roadbank vegetation, 5-V-1983, leg. L. Brako \& M.J. Dibben 6711 (NY). Idem, Bahia State, Serra de Rega, on bark of small vochyosiaceous tree in 
cerrado, cerrado with occasional tree islands, ca. $23 \mathrm{~km} \mathrm{~N}$ of Seabra, road to Agua de Rega, elev. ca. 1000 m, leg. H.S. Irwin, R.M. Harley \& G.L. Smith s.n., 24-II-1971 (NY 30946J). Idem, Minas Gerais State, Catas Altas Municipality, Parque Natural do Caraça, track to the Cascatinha, first $200 \mathrm{~m}$, on small tree thin twig in mesophyllous wood, leg. M.P. Marcelli \& A.E. Luchi 29789, 12-XI-1995 (SP). Idem, São Paulo State, Ibiúna Municipality, Morro Grande Neighborhood, SKY site, on small tree thin twig (Citrus sp.) in orchard, leg. M.P. Marcelli \& O. Yano 14618, 12-X-1992 (SP). Idem, Serra Negra Municipality, Alto da Serra, near the television tower, on isolate coconut tree stem in the hotel, leg. M.P. Marcelli, O. Yano \& A.B. Carvalho 22480, 04IV-1993 (SP). Idem, São Paulo Municipality, Parque Estadual da Cantareira, Núcleo da Pedra Grande, on tree trunk in illuminated woods, leg. M.P. Marcelli, A. Rezende \& O. Yano 13607, 18-V-1992 (SP). Idem, Santa Catarina State, Serra Geral, Serra Rio do Rastro, ca. $12 \mathrm{~km}$ W of Bom Jardim da Serra on road to Lauro Muller, at rim of summit plateau, $1470 \mathrm{~m} \mathrm{ca} .28^{\circ} 22 \times \mathrm{S}, 49^{\circ} 32^{\prime} \mathrm{W}$, humid hardwoods, 27-IX-1984, leg. D.M.Vital \& W.R.Buck 12370 p.p. (NY). Idem, Rio Grande do Sul State, Vacaria Municipality, Fazenda da Estrela, 28 $03^{\prime} 46.8^{\prime \prime S}, 50^{\circ} 57^{\prime} 33.7^{\prime \prime W}, 876 \mathrm{~m}$ alt., on branch of Podocarpus lambertii in edge of riparian wood, leg. L.S. Canêz \& A.A. Spielmann 1282, 10-I-2004 (SP).

Comments: The holotype (Fig. 14) consists of a small thallus in good condition, growing on a sliver of bark, indicating that the lower surface has never been examined yet. The lower cortex is difficult to see without removing the thallus from the substrate, but it is apparently black at the margins and dark brown otherwise. The type has only one mature apothecium with crenate margins containing ciliary bulbs. This kind of ciliary bulbs occurs also on other thallus parts. The amphithecium is maculate and has no isidia. The isotype in C mentioned by Hale (1976) was not found by the curator of that herbarium.

One of the most distinguishing characteristics of this species are the laminal ciliary bulbs, present in variable amounts (found in almost all thalli examined). These bulbs may appear all over the lamina, most often on young parts or those devoid of isidia, being bright and having an identical size and anatomy compared to those of the marginal cilia. Except in rare cases, they usually do not show formation of apices, much like those in the margins of the amphithecia. They are more massive and opaque than the pycnidia, which tend to have opaque brown or black ostioles, and are immersed in the thallus.

All bulbs have the same oily substance and idioblasts cells (Hale 1975, Feuerer and Marth 1997, Benati 2011), whether they are marginal, laminal or those that form the coronation of apothecia. No true pycnidia were found in the holotype.

In contrast to earlier publications (e.g., Hale 1976), the color of the lower surface was found to be not constantly black, but variable among specimens of $B$. ventricosa. It ranges from almost completely black to entirely brown, or to variable in color: (a) a brown to pale brown center with brown to dark brown margins, (b) a brown to dark brown center with dark brown margins, (c) a brown to black center with dark brown margins, (d) a brown to black center with pale brown margins, (e) a black to dark brown center with pale brown margins and (f) a black center with pale brown margins. 
Small specimens apparently tend to have an almost black lower surface, with dark brown margins and occasional few parts in the center, with a tendency to lighten as the thallus expands and develops. The margins of the lower cortex are initially distinct and lighter than the center until the brown color predominates on the lower surface, which usually occurs in some of the larger and older thalli.

Even with this tendency for variation apparently linked to thallus development, some developed thalli were found with a predominantly black to dark brown lower cortex, as well as some small thalli with a predominantly brown to pale brown lower cortex.

Apparently, Eliasaro (2001) was the only author to perceive the occurrence of different colors in the lower cortex, citing specimens with a variation from dark brown to black.

The discovery of the laminal bulbs and the constant citation of a black lower surface in the literature (Hale and Kurokawa 1964, Hale 1976) originally led to the hypothesis that there was a new undescribed species close to $B$. ventricosa, but the laminal bulbs and the variable colour of the lower cortex appeared to be characteristic for the species.

Bulbothrix ventricosa can be misidentified as B. tabacina when the lower cortex is black or as $B$. isidiza when it is more brownish. The three species are morphologically close and have similar spot test reactions (see differences below). Also Relicina abstrusa (Vainio) Hale has been confused with these, probably by the presence of a black lower surface, isidia, and medullary norstictic acid. Relicina abstrusa has, however, a yellowish upper cortex due to the presence of usnic acid, while the cilia have smaller bulbs in comparison to those of $B$. ventricos $a$ and are more evenly spaced and distributed along the margins. The ascospores are also smaller and rounded, 5.0-6.0 $\times 4.0-5.0 \mu \mathrm{m}$.

Vainio (1915), in describing B. ventricosa as Parmelia isidiza var. domingensis, believed it to be a variety of $P$. isidiza Nylander [Bulbothrix isidiza (Nylander) Hale], which curiously has a brown lower surface, and whose medulla (which contains salazinic acid instead of norstictic) reacts similarly to the $\mathrm{K}$ test. He noted the apothecia "without pycnidia adorning its margins" (absence of the bulbs that form the corona), and the laminal ciliary bulbs, but understood them as pycnidia, stating that he did not find conidia.

Because the name Parmelia domingensis was already used by Acharius (1814) for a species of Anaptychia [= Heterodermia domingensis (Acharius) Trevisan], Hale and Kurokawa (1964) proposed a new name and a new status for the taxon. The authors mentioned that $P$. ventricosa would be a Caribbean species with a disjoint locality in southern Africa, while $P$. isidiza would be a typically African species.

Bulbothrix tabacina (Montagne \& Bosch) Hale differs from B. ventricosa by the constantly black and shiny coloration of the lower cortex, the ecoronate apothecia and by the medullary chemistry due the presence of salazinic acid. Bulbothrix isidiza differs similar to B. tabacina, but has a overall brown lower cortex. Thalli of these species do not form laminal ciliary bulbs.

Bulbothrix cassa Jungbluth, Marcelli \& Elix is morphologically similar to B. ventri$\cos a$, but does not form laminal ciliary bulbs and its isidia are frequently ornamented 
with pycnidia. Bulbothrix cassa has a uniformly black lower cortex from the center to the margins, and by not forming any medullary substances (all spot tests negative).

\section{Bulbothrix viatica Spielmann \& Marcelli. Mycotaxon 103: 201. 2008.} Mycobank: MB 511147

Figures 16-17

Synonym. Bulbothrix megapotamica Canêz \& Marcelli. Mycotaxon 105: 225. 2008.

Holotype. Brazil, Rio Grande do Sul State, Santa Cruz do Sul Municipality, mar-

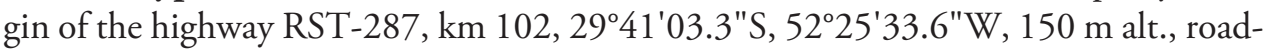
side, on Eucalyptus branch, 28-VII- 2003, leg. A.A. Spielmann 389 (SP!).

Description. Thallus sublinearly or subirregularly laciniate to sublaciniate, turning dusky green in the herbarium, fragments up to $5.3 \mathrm{~cm}$ diam., subcoriaceous to submembranaceous, corticicolous or ramulicolous; upper cortex 7.5-15.0 $\mu \mathrm{m}$ thick, algal layer 25.0-37.5 $\mu \mathrm{m}$ thick, medulla 37.5-72.5 $\mu \mathrm{m}$ thick, lower cortex 12.5-25.0 $\mu \mathrm{m}$ thick. Laciniae anisotomically dichotomously to irregularly branched, (0.4-) $1.1-4.7 \mathrm{~mm}$ wide, contiguous to sometimes slightly imbricate or rarely crowded in the center, adnate and loosely adpressed, with flat to slightly involute or revolute, subtruncate to subrotund apices, the margins flat to slightly involute, sinuous to crenate or subirregular, entire to slightly incised, rarely sublacinulate, axils oval to irregular, upper cortex continuous with irregular fissures in old parts, smooth to subrugose, laminal ciliary bulbs common, absent to abundant, usually frequent, mainly on young distal parts. Adventitious marginal lacinulae scarce on older parts, short, $0.2-1.2 \times 0.1-0.4 \mathrm{~mm}$, flat, simple to furcate or irregularly branched, apices subtruncate, lower side concolorous with the lower marginal zone. Maculae absent. Cilia black, with usually simple, sometimes double or absent, frequently downwardbent apices, $0.05-0.35(-0.60) \times \mathrm{ca} .0 .03 \mathrm{~mm}$, with emerse bulbate bases $0.05-0.15$ $(-0.35) \mathrm{mm}$ wide, frequent along the margins in the crenulations and axils of the laciniae, spaced $0.05-0.10 \mathrm{~mm}$ from each other, occasionally becoming contiguous, solitary or in small groups, absent or scarce at the apices of the laciniae and in some parts of the margins. Soredia, pustulae and isidia absent. Medulla white. Lower surface brown to dark brown, sometimes blackened in some small parts [black, mottled with brown in variable intermediary levels to completely brown], opaque to shiny, smooth to rugose, moderately rhizinate except at the margins. Marginal zone brown to pale brown, black or variegate, attenuated or indistinct from the center, shiny, $0.5-4.0 \mathrm{~mm}$ wide, smooth to subrugose or subvenate, papillate, becoming rhizinate towards the center. Rhizinae black to dark or pale brown, occasionally with whitish apices, simple or rare irregularly branched, partially with bulbate bases, $0.10-0.50$ $(-0.80) \times 0.03-0.05 \mathrm{~mm}$, frequent but sometimes becoming more abundant at some spots, evenly distributed. Apothecia subconcave to concave or urceolate, occasionally subplane, adnate to substipitate, $0.5-5.4 \mathrm{~mm}$ diam., laminal, margins smooth to crenate, coronate (bulbs appearing in the crenulations), amphithecium smooth 
to rugose without ornamentations. Disc brown to pale brown, epruinose, imperforate, epithecium 7.5-12.5 $\mu \mathrm{m}$ high, hymenium 55.0-75.0 $\mu \mathrm{m}$ high, subhymenium 12.5-27.5 $\mu \mathrm{m}$ high. Ascospores ellipsoid to oval, (10.0-) 12.0-16.0 (-18.0) $\times$ $(6.0-) 7.0-10.0(-11.0) \mu \mathrm{m}$, epispore $1.0-1.5 \mu \mathrm{m}$. Pycnidia frequent, submarginal to laminal, immerse, with brown or black ostioles; conidia weakly to distinctly bifusiform (4.0-) 5.0-7.5 × $1.0 \mu \mathrm{m}$.

Spot tests. upper cortex $\mathrm{K}+$ yellow, UV-; medulla $\mathrm{K}+$ yellow $\rightarrow$ orange or light red, C-, KC-, P+ orange, UV-.

TLC/HPLC. cortical atranorin, medullary norstictic and connorstictic acids (see also Spielmann 2005, Spielmann and Marcelli 2008).

Distribution. South America. Brazil: Rio Grande do Sul (Canêz 2005, Spielmann 2005, Marcelli and Canêz 2008, Spielmann and Marcelli 2008) and São Paulo (Jungbluth 2006). Here is cited for the Brazilian States of Goiás, Minas Gerais, and Rio de Janeiro.

Additional specimens examined. Brazil, Goiás State, Serra Geral do Paranã, on bark of Kielmeyera, in cerrado, cerrado and campo on slopes, ca. $1 \mathrm{~km} \mathrm{~S}$ of São João Aliança, ca. 850 m, leg. Irwin et al. 31977a, 16-III-1971 (NY). Idem, ca. 10 km S of São João da Aliança, campo e cerrado, cerrado, on trunk of small tree (Hymenaea sp.), 950 m, leg. H. S. Irwin, R. M. Harley \& G. L. Smith 32074, 17-III-1971 (US). Idem, Minas Gerais State, Catas Altas Municipality, Serra do Caraça, Parque Natural do Caraça, , on tree trunk at the foot of the Morro do Calvário at the side of the hotel, leg. M.P. Marcelli \& A.E. Luchi 29654, 10-XI-1995 (SP). Idem, Rio de Janeiro State, leg. A. Glaziou 1825 (UPS). Idem, São Paulo State, Santa Rita do Passa Quatro Municipality, Vassununga farm, Anhanguera Highway km 259, on thin small tree thin twig in the dense cerrado, leg. M.P. Marcelli \& C.H. Ribeiro 17508, 15VI-1979 (SP). Idem, Rio Grande do Sul State, Sinimbu Municipality, Cava Funda, $29^{\circ} 27^{\prime} 40 " \mathrm{~S}, 52^{\circ} 31^{\prime} 09.5^{\prime \prime} \mathrm{W}$, corticicolous, in the embankment of the road in open place, leg. A.A. Spielmann \& L.S. Canêz 1318, 05-I-2004 (SP). Idem, Herveiras Municipality, $29^{\circ} 27^{\prime} 12.5^{\prime \prime} \mathrm{S}, 52^{\circ} 37^{\prime} 57.7^{\prime \prime} \mathrm{W}, 540 \mathrm{~m}$ alt., in trunk of Eucalyptus sp., in the embankment of the road in open place, leg. A.A. Spielmann, L.S. Canêz \& C. Trentin 714, 24-I-2004 (SP). Idem, Sobradinho Municipality, margin of RST-481 road, near the road clover, $29^{\circ} 24^{\prime} 20.2^{\prime \prime S}, 52^{\circ} 01^{\prime} 25.9^{\prime \prime} \mathrm{W}, 375 \mathrm{~m}$ alt., corticicolous in bush in the embankment in open place, leg. A.A. Spielmann 341, 17-VII-2003 (SP). Idem, Vacaria Municipality, Fazenda da Estrela, 28 $04^{\prime} 58.9^{\prime \prime S}, 50^{\circ} 56^{\prime} 48.9^{\prime \prime W}, 850 \mathrm{~m}$ alt., open field, on a shrub branch, 23-II-2003, leg. L.S. Canêz \& A.A. Spielmann 146 (holotype of $B$. megapotamica, SP!).

Comments. The holotype (Fig. 16) is a small fragmented piece in excellent condition, free of substrate, with a predominantly brown lower surface. The upper surface contains many laminal bulbs and pycnidia, and several well-developed apothecia, containing mature ascospores.

Bulbothrix viatica is probably the parental non-isidiate morph of $B$. ventricosa. Both are very similar in almost all characteristics (especially regarding the color variation of the lower cortex and the frequent presence of laminal ciliary bulbs), differing almost only by the presence of cortical maculae and isidia in B. ventricosa. 
The same color variations found in the lower cortex of specimens of $B$. viatica were also found in specimens of $B$. ventricosa (see there). The most common is different tinges of brown mixed with dark or blackish spots of variable sizes (as in the holotype), but some thalli, especially the smaller ones, tend to have a darker or black coloration.

The laminal ciliary bulbs were overlooked by Spielmann and Marcelli (2008). They are clearly present in part of the material cited by these authors, including the holotype. Admittedly, specimens without laminal bulbs do also occur and are more common in $B$. viatica than in $B$. ventricosa. The structure of the laminal bulbs is the same as in $B$. ventricosa (see above). The eventual appearance of these bulbs in these species might be conditioned to thallus development and environmental stimuli.

As shown by Marcelli and Canêz (2008), there are at least three morphologically similar species, with norstictic acid and simple cilia with globose bulbate bases, common in the southern and southeastern regions of Brazil which formerly included in $B$. subcoronata. They are differentiated by the size of the ascospores, the presence or absence of laminal ciliary bulbs and the coloration of the lower cortex. The ones currently known are $B$. regneliana, $B$. ventricosa and $B$. viatica and possibly true $B$. subcoronata. The specimens with a brown lower surface with ascospores $7-11 \mu \mathrm{m}$ long reported by Hale (1976) as B. subcoronata are possibly B. regnelliana, while the specimens with ascospores (10-) 12-18 (-20) $\mu \mathrm{m}$ long and a black or brown lower surface cited in other works might be $B$. viatica.

Accordingly to the literature, B. subcoronata (Müller Argoviensis) Hale is the species most easily confusable with $B$. viatica, but it has narrower and more sublinear laciniae (ca. 0.5-1.0 mm wide), no laminal ciliary bulbs, a black lower cortex with distinct brown margins, and retrorse rhizinae on the apothecia. The ascospores are smaller, more rounded (5.0-7.5 × 4.0-5.5 $\mu \mathrm{m})$ than described by Müller Argoviensis (1887).

The holotype of $B$. megapotamica Canêz \& Marcelli has narrow and truncate laciniae (0.5-1.5 mm wide), lacks laminal ciliary bulbs (with many pycnidia), and a black lower surface with brown margins, and almost no formation of bulbs in the rhizinae (the few seen are subtle). However, there are specimens with intermediary characteristics who show that $B$. megapotamica is a synonym of $B$. viatica.

Bulbothrix hypocraea (Vainio) Hale differs from B. viatica by the absence of ciliary bulbs on a maculate upper cortex, a predominantly ochraceously or creamy pale brown lower surface, creamy or pale brown rhizinae, ecoronate apothecia with ascospores $8.0-14.0 \times 6.0-8.0 \mu \mathrm{m}$ and the presence of medullary salazinic acid. The similar Bulbothrix continua (Lynge) Hale is also emaculate, but has narrower (ca. 1.0-2.0 mm wide) and dichotomous sublinear laciniae and contains salazinic acid in the medulla.

Bulbothrix linteolocarpa Marcelli differs by the very narrow, sublinear laciniae (ca. 0.3-0.5 mm wide), a pale brown lower cortex with darker margins, simple to furcate or irregularly branched rhizinae, ecoronate flat apothecia stretched over the laciniae, and salazinic acid in the medulla.

Bulbothrix setschwanensis (Zahlbruckner) Hale differs by having a pale brown lower surface with indistinct margins, rhizinae without basal bulbs, ecoronate apothecia containing ascospores $12.0-19.0 \times 6.0-9.0 \mu \mathrm{m}$, and medullary salazinic acid. 
Bulbothrix meizospora (Nylander) Hale differs by the larger laciniae $(1.5-6.0 \mathrm{~mm}$ wide), a shiny black lower surface with distinct brown margins, ecoronate apothecia with larger ascospores $(12.0-20.0 \times 8.0-12.0 \mu \mathrm{m})$, and medullary salazinic acid. Bulbothrix sensibilis (Steiner \& Zahlbruckner) Hale differs by almost the same characteristics, but has smaller ascospores, 7.0-11.0 × 5.0-7.0 mm.

\section{Acknowledgements}

The author wishes to thank the curators of B (Robert Vogt), BM (Scott LaGrecca), CANB (Brendan Lepschi), DUKE (Kathleen Pryer), G (Philippe Clerc), ICN (Mara Rejane Ritter), NY(Barbara Thiers), TUR (Seppo Huhtinen), UPS (Stefan Ekman), US (Rusty Russell) and Dr. Klaus Kalb for the loan of the type specimens and additional material, Dr. Jack A. Elix for HPLC data on the species substances, Dr. Michaela Schmull and Genevieve Lewis-Gentry for the English review, comments, and suggestions, Dr. Luciana Canêz for the discussions about morphological characters found in $B$. cinerea and the reviewers for critical revision of the manuscript.

\section{References}

Acharius E (1814) Synopsis methodica lichenum. Lund.

Benatti MN (2010) Revisão taxonômica do gênero Bulbothrix Hale (Parmeliaceae, Ascomycota liquenizados) [Doctoral Thesis]. Instituto de Botânica. São Paulo, 401p.

Benatti MN (2011) A simple clearing technique to aid in the recognition of cilia and rhizinae struture in the Parmeliaceae. Opuscula Philolichenum 9: 21-25.

Benatti MN, Marcelli MP (2010) Four Parmeliaceae species excluded from Bulbothrix. Mycotaxon 111: 387-401. doi: 10.5248/111.387

Brako L, Dibben MJ, Amaral I (1985) Preliminary Notes on the macrolichens of Serra do Cachimbo, Northcentral Brazil. Acta Amazonica, suplement 15(1-2): 123-135.

Calvelo S, Liberatore S (2002) Catalogo de los líquenes de la Argentina. Kurtziana 29(2): 7-170.

Canêz LS (2005) A Família Parmeliaceae na localidade de Fazenda da Estrela, Município de Vacaria, Rio Grande do Sul, Brasil. Dissertação de Mestrado. Instituto de Botânica, São Paulo.

Crespo A, Kauff F, Divakar PK, del Prado R, Pérez-Ortega S, de Paz GA, Ferencova Z, Blanco O, Roca-Valiente B, Núńez-Zapata J, Cubas P, Argüello A, Elix JA, Esslinger TL, Hawksworth DL, Millanes AM, Molina MC, Wedin M, Ahti T, Aptroot A, Barreno E, Bungartz F, Calvelo S, Candan M, Cole MJ, Ertz D, Goffinet B, Lindblom L, Lücking R, Lutzoni F, Mattsson J-E, Messuti MI, Miadlikowska J, Piercey-Normore MD, Rico VJ, Sipman H, Schmitt I, Spribille T, Thell A, Thor G, Upreti DK, Lumbsch HT (2010) Phylogenetic generic classification of parmelioid lichens (Parmeliaceae, Ascomycota) based on molecular, morphological and chemical evidence. Taxon 59: 1735-1753. 
Eliasaro S (2001) Estudio taxonomico y floristico sobre las parmeliaceae sensu stricto (Ascomycota liquenizados) del Segundo Planalto del Estado de Paraná, Brasil. Tese de Doutorado. Universidad de Buenos Aires.

Eliasaro S, Adler MT (1997) Two new species and new reports in the Parmeliaceae sensu stricto (lichenized Ascomycotina) from Brazil. Mycotaxon 63: 49-55.

Elix JA (1993) Progress in the generic delimitation of Parmelia sensu lato lichens (Ascomycotina: Parmeliaceae) and a synoptic key to the Parmeliaceae. The Bryologist 96(3): 359-383.

Elix JA (1995) New species in the lichen family Parmeliaceae (Ascomycotina) from Australasia and Malaysia. Mycotaxon 56: 231-241.

Elix JA (1996) A Revision of the Lichen Genus Relicina. Bibliotheca Lichenologica 62, J. Cramer, Berlin, Stuttgart.

Elix JA, Giralt M, Wardlaw JH (2003) New chloro-depsides from the lichen Dimelaena radiata. Bibliotheca Lichenologica 86: 1-7.

Feuerer T, Marth C (1997) Anatomy of pseudocyphellae and bulbate cilia in Parmeliaceae. Mitteilungen aus dem Institut für Allgemeine Botanik in Hamburg 27: 101-107.

Fleig M (1985) Estudo preliminar da Família Parmeliaceae (liquens) no Rio Grande do Sul, Brasil. Comunicaçôes do Museu de Ciências da Pontifícia Universidade Católica do Rio Grande do Sul (PUCRS), Série Botânica, Porto Alegre 35: 79-91.

Hale ME (1972) Six new species of Parmelia from Africa. Phytologia 23: 343-349.

Hale ME (1974) Bulbothrix, Parmelina, Relicina, and Xanthoparmelia, four new genera in the Parmeliaceae. Phytologia 28: 479-490.

Hale ME (1975) A Monograph of the Lichen Genus Relicina (Parmeliaceae). Smithsonian Contributions to Botany 26: 1-32. doi: 10.5479/si.0081024X.26

Hale ME (1976) A Monograph of the Lichen Genus Bulbothrix Hale (Parmeliaceae). Smithsonian Contributions to Botany 32: 1-29.

Hale ME, Kurokawa S (1964) Studies on Parmelia subgenus Parmelia. Contributions from the United States national Herbarium 36(4): 121-191.

Jungbluth P (2006) A família Parmeliaceae (fungos liquenizados) em fragmentos de cerrados do Estado de São Paulo. Dissertação de Mestrado. Instituto de Botânica, São Paulo.

Jungbluth P, Marcelli MP, Elix JA (2008) Five new species of Bulbothrix (Parmeliaceae) from cerrado vegetation in São Paulo State, Brazil. Mycotaxon 104: 51-63.

Lopez-Figueiras M (1986) Censo de macroliquenes venezolanos de los estados Falcon, Lara, Merida, Tachira y Trujillo. Facultad de Farmacia, Universidad de Los Andes, Merida.

Marcano V, Morales-Méndez A, Sipman H, Calderon L (1996) A first checklist of the lichenforming fungi of the Venezuelan Andes. Tropical Bryology 12: 193-235.

Marcelli MP (1993) Pequenas Parmelia s.l. Ciliadas dos Cerrados Brasileiros. Acta Botanica Brasilica 7(2): 25-70. doi: 10.1590/S0102-33061993000200003

Marcelli MP, Canêz LS (2008) Novelties on Southern Brazilian Parmeliaceae. Mycotaxon 105: 225-234.

Marcelli MP, Ribeiro CH (2002) Twenty-one new species of Parmeliaceae (lichenized fungi) from southeastern Brazil. Mitteilungen aus dem Institut für Allgemeine Botanik Hamburg 30-32: 125-155. 
Müller Argoviensis J (1887) Lichenologische Beiträge XXVI. Flora 70(32): 316-322.

Papong K, Boonpragob K, Lücking R (2007) New species and new records of foliicolous lichens from Thailand. Lichenologist 39(1): 47-56. doi: 10.1017/S0024282906006104

Ribeiro CH (1998) A família Parmeliaceae (Ascomycota liquenizados) em regióes montanhosas dos Estados de Minas Gerais, Rio de Janeiro e São Paulo. Dissertação de Mestrado, Universidade de São Paulo.

Sinha GP, Singh KP (1986) Three new records of foliose lichens from Nagaland (India). Current Science 55(14): 661-662.

Spielmann AA (2005) A família Parmeliaceae (fungos liquenizados) nos barrancos e peraus da encosta da Serra Geral, no Vale do Rio Pardo, Rio Grande do Sul, Brasil. Dissertação de Mestrado. Instituto de Botânica, São Paulo.

Spielmann AA, Marcelli MP (2008) Bulbothrix viatica Spielmann \& Marcelli, a new species of Parmeliaceae from Brazil. Mycotaxon 103: 201-205.

Swisncow TDV, Krog H (1988) Macrolichens of East Africa. British Museum of Natural History. London.

Vainio (Wainio) EA (1915) Additamentum ad lichenographiam Antillarum illustrandam. Annales Academiae Scientiarum Fennicae A6, 7: 1-226. 